\title{
Impact of land configurations on soil moisture and productivity of cotton under rainfed conditions
}

\author{
M.P. Sathe, S.A. Lad and M.G. Kale
}

Received : 06.09.2019; Revised : 11.11.2019; Accepted : 20.11 .2019

MEMBERS OF RESEARCH FORUM:

Corresponding author :

M.P. Sathe, Post Graduate Institute

Dr. Pajabrao Deshmukh Krishi

Vidyapeeth, Akola (M.S.) India

Email: maheshsathe03@gmail.com

Co-authors :

S. A. Lad and M.G. Kale, Post

Graduate Institute

Dr. Pajabrao Deshmukh Krishi

Vidyapeeth, Akola (M.S.) India

\section{Summary}

In order to study the in situ soil and water conservation measures and the impact of soil and water conservation measures in terms of increase in soil moisture content, biometric observations, moisture use and production efficiency, reduction in runoff, soil and nutrient losses, three land configurations were studied for soil-water management, viz., cultivation along the slope with opening of tide furrow $\left(\mathrm{T}_{1}\right)$, contour cultivation with opening of alternate furrow $\left(\mathrm{T}_{2}\right)$ and contour cultivation with opening of ridges and furrows $\left(\mathrm{T}_{3}\right)$. The present investigation revealed that the treatment $\mathrm{T}_{3}$ was more prominent and favourably influenced the crop growth, soil moisture, moisture use and production efficiency, cost benefit ratio due to the drastic change in the runoff hydrograph characteristics and reduction in runoff, soil loss and nutrient losses, followed by treatment $T_{2}$ over the treatment $T_{1}$. In the context of above results, it is concluded that the in situ soil and water conservation measures is the need of day in rainfed agriculture for the management of erratic and vagarious rainfall under the changing climatic conditions. From the study of the rainfall characteristics like duration, intensity classification, frequency distribution of rainy days, kinetic energy of rainstorms and erosion index, it is revealed that out of 47 rainy days, 41 rainy days were commenced with rainfall intensity $<25 \mathrm{~mm} \mathrm{hr}^{-1}$ and 6 rainy days were commenced with $25-50 \mathrm{~mm} \mathrm{hr}^{-1}$ rainfall intensity.

Key words : Land configurations, Soil moisture, Cotton under rainfed conditions

How to cite this article : Sathe, M.P., Lad, S.A. and Kale, M.G. (2019). Impact of land configurations on soil moisture and productivity of cotton under rainfed conditions. Asian J. Soil Sci., 14 (1\&2) : 52-56 : DOI : 10.15740/HAS/AJSS/14.1and2/52-56. 